\title{
Grundtvigs oplysningstanker - om at knytte bånd og løse knuder
}

\author{
Af Ove Korsgaard
}

Langt de fleste af de mange bøger og artikler, der er skrevet om Grundtvigs skoletanker, kan opdeles i to hovedkategorier. Den ene med overskriften: Grundtvigs poedagogiske tanker. Den anden: Den grundtvigske højskole. De to professorer på Danmarks Lærerhøjskole, K.E. Bugge og Roar Skovmand, var gennem flere årtier i sidste halvdel af det forrige århundrede autoriteter på hver deres område. I det autoritative skrift Grundtvig og grundtvigianisme i nyt lys, der udkom i 1983, er det da også K.E. Bugge, der skriver om »Grundtvigs pædagogiske tanker«, og Roar Skovmand, der belyser »Den grundtvigske folkehøjskole«.

I det følgende vil jeg argumentere for nødvendigheden af at tilføje en tredje kategori med overskriften: ॥Grundtvigs oplysningstanker«. Den pædagogiske og den skolehistoriske tilgang har bevirket, at der er sider af Grundtvigs oplysningstanker, der ikke for alvor er blevet belyst. Men først en kort omtale af de to kendte kategorier.

\section{Grundtvigs padagogiske tanker}

Ifølge K.E. Bugge kan den gængse opfattelse af hovedindholdet i Grundtvigs skoletanker opsummeres i følgende punkter: ${ }^{1}$

1. Fremhævelsen af ungdomstiden - modsat barnealderen - som den egentlige skoletid;

2. Fremhævelsen af den mundtlige undervisnings, specielt det åndsbårne foredrags inciterende, vækkende betydning;

3. Fremhævelsen af den dansk-nordiske kulturtradition, modsat den klassisklatinske, som det bedste fundament for undervisningen;

4. Fremhævelsen af, at disse tanker på en eller anden måde er knyttet sammen med et kristent livssyn. 
K.E. Bugge tager dog forbehold, når det gælder punkt fire, idet han afviser, at Grundtvig direkte inddrager kristne trosforestillinger i bestemmelsen af opdragelsens mål.

Selv betragter K.E. Bugge begrebet »vekselvirkning" som nøglen til forståelse af det specielle ved Grundtvigs tanker om undervisning og opdragelse. Vekselvirkning er den grundkategori, der gennemsyrer hans pædagogiske tanker. Undervisningen skal bygge på en levende vekselvirkning mellem elever og lærer, mellem eleverne indbyrdes, samt mellem folkets liv i fortid og nutid. For at få en levende vekselvirkning mellem fortid og nutid skal undervisningen både være poetisk og historisk. Man kan kort sige, at for Grundtvig er poesi forbundet med skabelse, og historie med udvikling. Poesi er efterligning af skabelsens orden, og historie en udvikling mod genetablering af denne orden. Der er ingen tvivl om, at det i særlig grad er den historisk-poetiske metode, der har givet Grundtvigs pædagogiske tanker deres særpræg. ${ }^{2}$

\section{Den grundtvigske højskole}

Roar Skovmand begynder selvfølgelig sin beretning om »Den grundtvigske folkehøjskole« med oprettelsen af Rødding Højskole i 1844. Men Rødding var ikke nogen umiddelbar virkeliggørelse af Grundtvigs skoletanker, om end især professor Christian Flor var stærkt påvirket af Grundtvigs ideer. Grundtvig fortsatte med at knytte store forhåbninger til oprettelsen af en slags folkeuniversitet på Sorø Akademi, der ikke alene skulle henvende sig til vordende embedsmænd, men også til bredere kredse af befolkningen. Det var derfor en stor skuffelse for Grundtvig, da den nye regering i 1848 henlagde planerne om en højskole i Sorø.

De tyve år fra 1844 til 1864 gav ikke noget entydigt fingerpeg om, at Grundtvigs navn skulle blive uløseligt knyttet sammen med højskolen. Af de 14 »bondehøjskoler«, der fandtes i 1862-63, var de fleste i virkeligheden fortsættelsesskoler for drenge. Det var først efter nederlaget i krigen mod Preussen og Østrig i 1864, at højskolebevægelsen tog fart. Etableringen af Askov Højskole i 1865 blev indledningen til den store højskoletid, der i løbet af de næste 10 år førte til oprettelse af omkring 50 højskoler - de fleste grundtvigske. 
Men ikke kun i Danmark blev der oprettet højskoler. Det samme skete i Sverige, Norge og Finland. Omkring århundredeskiftet havde folkehøjskolerne i de fire nordiske lande fâet deres nationale særpræg. »Men så forskellige de var samledes deres lærere og ledere af og til ved nordiske folkehøjskolemøder for at bekræfte deres samhørighed - og vedkende sig inspirationen fra Danmark og dets grundtvigianere - eller fra Grundtvig selv« ${ }^{3}$ Også i mange andre lande er der i det 20. århundrede blevet oprettet skoler med henvisning til Grundtvig og den grundtvigske folkehøjskole som inspirationskilde.

Folkehøjskolen har virket stærkt fascinerende på mange skolefolk verden over; og det har bidraget til, at Grundtvigs skoletanker og højskolens historie næsten er vokset sammen til to sider af samme sag. Højskolen er blevet set som en vellykket institutionalisering og en materialisering af Grundtvigs pædagogiske ideer.

At der er en tæt forbindelse mellem Grundtvigs ideer om oplysning og den grundtvigske folkehøjskole, kan ingen benægte. Derimod kan det diskuteres, i hvor høj grad højskolen er en realisering af Grundtvigs samlede oplysningsprogram.

\section{Grundtvigs tre sferer}

Som K.E. Bugge har påpeget, er det vigtigt at gøre sig klart, at Grundtvig ikke er optaget af pædagogik i snæver forstand. Han er ikke en teoretisk pædagogisk tænker, der udvikler sit eget pædagogiske system. Han er heller ikke praktisk pædagog, om end han holder en række foredrag på Marielyst Højskole i årene 1856-71.

Grundtvigs højskoleideer kan betragtes som et biprodukt, der primært vokser ud af hans politiske og nationale engagement. Det er således ingen tilfældighed, at det er i Grundtvigs første politiske skrift - Politiske Betragtninger med Blik paa Danmark og Holsteen fra 1831 - at han først slår til lyd for en »højskole for folkelig videnskabelighed og borgerlig uddannelse«, der kunne uddanne de ustuderede. ${ }^{4}$ Oprettelsen af de rådgivende stænderforsamlinger samme år får ligeledes helt afgørende betydning for Grundtvigs skoletanker. Det er forfatningsspørgsmålet og de forfatningspolitiske reformer, der bliver årsag til Grundtvigs entré til polissfæren, og den direkte anledning til, at 
han i 1830'erne og 1840'erne skriver en række skoleskrifter, hvori han argumenterer for nødvendigheden af at oprette en ny skoleform, nemlig en folkehøjskole.

Men faktisk blev væsentlige sider af Grundtvigs oplysningsprogram udviklet allerede i Danne-Virke-skrifterne 1816-19. I artiklen $॥$ Kirke, Stat og Skole« fra 1819 fremhæver Grundtvig, at det almindelige mål med skolen er at gøre mennesker til duelige samfundsborgere; han mener imidlertid ikke, det kan være dens endelige mål, og spørger: „Hvad bør nu Skolens Øiemed være, eller: hvortil bør man i Skolen stræbe at udvikle og danne Mennesket? « Og hans eget svar på spørgsmålet er bemærkelsesværdigt klart: "Skolen skal stræbe at udvikle Mennesket til Fuldkommenhed, og følgelig stræbe, af alle de Enkelte at danne saa duelige Medarbeidere til dette Maal som mueligt ${ }^{5}{ }^{5}$

Som god kristen afviser Grundtvig selvfølgelig, at mennesket ved egen kraft kan fuldkommengøre sig selv. For Grundtvig er det fuldendte menneske kun fuldt udfoldet i Kristus. Alligevel opstiller han fuldkommenhed som skolens mål. Selv om mennesket ikke kan frelse sig selv, kan det godt gøre noget selv. Selv om den menneskelige fornuft ikke kan begribe Gud, så kan det godt komme til at begribe sig selv som et åndeligt væsen indfældet i skaberværket. "At begribe sig selv i Sandhed er da det store Maal for den menneskelige Fornuft, Høiden af Menneskelig Vidskab «. ${ }^{6}$

Vidskab er Grundtvigs ord for filosofi. «Philosophie er som man veed Udtryk for den menneskelige Stræben efter Visdom, dvs. fuldkommen Erkiendelse, umiddelbar Anskuelse, og med det høieste christlige Udtryk: Beskuelse Ansigt til Ansigt, Det danske ord, vi da bedst kunne vælge til betegne denne Stræben i sin Livlighed er uden tvivl Vidskab «. ${ }^{7}$ At skue ansigt til ansigt, er Grundtvigs metafor for det universelle.

Perspektivet i Danne-Virke er langt mere specifikt i sin universalistiske livsopfattelse end senere i forfatterskabet. Et af Grundtvigs vigtigste skrifter fra denne periode hedder meget karakteristisk »Om Mennesket i Verden ${ }^{8}{ }^{8}$ Titlen peger på, at Grundtvig her i særlig grad beskæftiger sig med »mennesket i verden «; dvs. forholdet mellem det individuelle og det universelle. Det universelle er for Grundtvig først $\mathrm{og}$ fremmest ensbetydende med det verdenshistoriske og ikke mindst det religiøse perspektiv.

Efter 1832 beskæftiger han sig hovedsagelig med "mennesket i samfundet", dvs. forholdet mellem det individuelle og det folkelige/statslige. Det har med- 
ført, at Grundtvigs skoletanker ofte er blevet reduceret til kun at omhandle to sfærer: den enkelte og folket. En sådan reduktion giver imidlertid en misvisende forståelse af hans oplysningsprogram. Thi også efter 1832 indgår der tre sfærer, om end det universelle perspektiv ind imellem fortoner sig i det politiske. Men det er ikke desto mindre intakt i salmerne og i de store kosmologiske digte.

Grundtvigs højskoletanker udgør således kun en del af et mere omfattende oplysningsprogram, hvis indhold er bestemt af de grundmenneskelige problemstillinger, han beskæftigede sig med livet igennem:

- Hvad vil det sige at være menneske?

- Hvad vil det sige at være menneske i samfundet?

- Hvad vil det sige at være menneske i verden?

Grundtvigs oplysningstanker kan siges at relatere sig til de universalhistoriske treklang mellem: »Enkeltmanden«, »Folket/Staten« og »hele Menneskeslægten«. Sagt på en anden måde: det er forbindelsen mellem det individuelle, folkelige og universelle, der udgør den grundlæggende struktur i Grundtvigs skoletanker. Opgaven er, siger Grundtvig, at »Udvikle en fuldstændig menneskelig Oplysning«, der skal have en trefoldig virkning, nemlig at opklare:

- "Hverdags-Livet for Øieblikket«

- »Folke-Livet giennem Aarhundreder« og

- »Menneske-Livet i Aar-Tusinder «. ${ }^{9}$

Hos Grundtvig er hverdagslivet indskrevet i tidsdimensioner, der rækker ud over »øjeblikket«; det er indfældet i såvel folkelivet som menneskelivet. Mens den enkeltes liv kan tælles i årtier, kan folkets liv tælles i århundreder, og menneskeslægtens liv i årtusinder. 


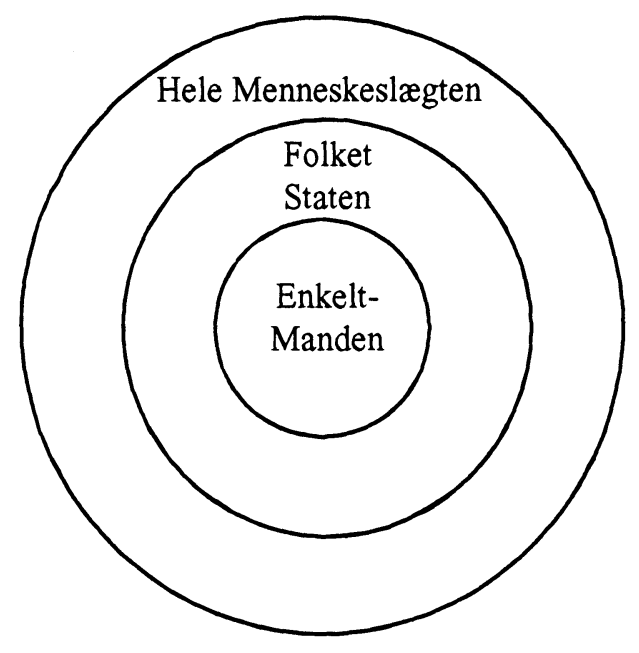

\section{Grundtvigs to institutioner}

Grundtvigs uhyre ambitiøse plan var at etablere et skolesystem, der byggede på to søjler: folket og menneskeslægten. Den ene skulle bære højskolen, den anden universitetet. Mellem de to institutioner er der en form for arbejdsdeling. På folkehøjskolen er opgaven at fremme livsdueligheden og folkelivet; på universitetet at undersøge og forklare det universelle i menneskelivet. At fă sat erkendelsen af det universelle på begreb, er en opgave for universitetet, ikke for højskolen.

De to institutioner refererer imidlertid ikke kun til to formelt forskellige uddannelsesniveauer; de bygger også på forskellige forståelseshorisonter, henholdsvis en folkelig og en mere universel erkendelses- og livshorisont.

Grundtvig bruger i sine skrifter forskellige betegnelser om de to slags skoler, han drømte om: En dansk højskole og en videnskabelig højskole, højskolen i Soer og universitetet i Gøteborg, "Skolen for Livet" og "Skolen for Lyst«.

I stikordsform kan de to skoleformer skitseres på følgende måde: 


$\begin{array}{ll}\text { Sorø } & \text { Göteborg } \\ \text { Folkehøjskolen } & \text { Universitetet } \\ \text { Folke-lighed } & \text { Menneske-lighed } \\ \text { Folkelig oplysning } & \text { Videnskabelig oplysning } \\ \text { Det nationale } & \text { Det universelle } \\ \text { Skolen for livet } & \text { Skolen for Lyst }\end{array}$

Det er almindeligt at henvise til Nordens Mytologi fra 1832 og Om Nordens videnskabelige Forening fra 1839 som programskrifter for henholdsvis folkehøjskolen og universitetet.

Grundtvigs samlede skolesyn kommer imidlertid i særlig grad til udtryk i udkastet Statsmoessig Oplysning fra 1834, der først blev trykt og udgivet ved K.E. Bugge og Vilhelm Nielsen i 1983. Skriftet er en skitse til et samlet skoleprogram, hvis to centrale institutioner er folkehøjskolen og universitetet. $\mathrm{Og}$ som Vilhelm Nielsen anfører, så kaster skriftet et særligt lys over de senere skoleskrifter, idet en »række ting blev aldrig sagt så skarpt og klart i de egentlige højskoleskrifter som her . $^{10}$

I manuskriptet er den centrale problemstilling forholdet mellem enkeltmanden, staten/folket og hele menneskeslægten. Grundtvig taler ikke kun om enkeltmanden som et særligt individ, men også om enkeltmandstiden som en bestemt epoke i verdenshistorien. Han bruger udtrykket enkeltmandstiden $\mathrm{i}$ forbindelse med beskrivelsen af nytårstiden, hvis begyndelse han i 1843 knytter sammen med Columbus, altså med renæssancen. ${ }^{11}$ Andre og flere steder henviser han til Luther som indgangsportalen til nytårstiden, som han også kalder eftertankens tidsalder.

Ligesom andre store universalhistorikere tænkte Grundtvig historien ud fra tallet tre. Menneskeslægtens historie gennemløber tre store tidsepoker, som han bruger forskellige begreber om, der korresponderer indbyrdes. Han taler om en mytologisk, teologisk og historisk periode, om Faderens, Sønnens og Helligåndens tidsalder, om kirkens, statens og skolens epoke, om fantasiens, følelsens og forstandens tid. Kirken (fantasien) udtrykker menneskets forhold til Gud, staten (følelsen) menneskets forhold til andre, skolen (forstanden) menneskets forhold til sig selv. Ifølge Grundtvig lever vi nu i historiens, Helligåndens og skolens tidsalder. ${ }^{12}$ 
I Grundtvigs terminologi er skolens epoke også enkeltmandens epoke. Skolens tidsalder er individualiseringens tidsalder. Her er det menneskets forhold til sig selv, der kommer i centrum.

Enkeltmandstidens stigende selvbevidsthed betyder nye vilkår for samfundsdannelsen. I Grundtvigs optik betyder det, at oplysning kommer til at spille en langt større rolle end tidligere for relationen mellem individ og samfund. Skolen bliver nu samfundets centrum.

Sammenlignet med oldtiden og middelalderen træder enkeltmanden i skoletiden $i$ en helt anden grad end tidligere frem på historiens scene. Denne individualisering, som Columbus og Luther symboliserer, betragter Grundtvig som en vigtig, men også en yderst farlig fase i den universalhistoriske udvikling. Den franske revolution 1789 viser hvor farlig. Her blev forholdet mellem den enkeltes frihedstrang og staten som varetager af det fælles bedste ødelagt med fatale følger.

På trods af erfaringerne med den franske revolution og faren for, at friheden undergraver den for samfundet nødvendige sans for det fælles bedste, argumenterer Grundtvig ikke for mindre frihed end tidligere, men for mere. At være medlem af et samfund betyder at påtage sig et ansvar for dets fælles liv. Og det sikres bedst, hvis der i samfundet er frihed for individet til selv at påtage sig et ansvar. Grundtvigs samfundsfilosofi bygger på det synspunkt, at kun i frihed vil individet frivilligt pålægge sig de nødvendige bånd.

Grundtvig argumenterer på ingen måde for den totale individuelle frihed. En sådan forståelse af frihed vil i det lange løb føre til samfundets opløsning. For samfundsborgeren eksisterer den ubegrænsede frihed ikke. Absolut individualisme er for Grundtvig uforenelig med en forestilling om samfund.

Ethvert samfund er nemlig afhængigt af bånd mellem enkeltmanden og staten. Samfundsdannelse beror altid på en vis enighed om det fælles bedste; wthi hvor en saadan Grund-Enighed ikke spores, der har aldrig dannet sig et Borgerligt Selskab, men kun en Herre-Stand og Trælle-Stand i skarp Modsætning, der vel tilsammentagne kan kaldes en stat, men er dog ingenlunde, hvad vi her tale om, da i en saadan Kreds »den Stærkes Ret« unægtelig er GrundLoven ${ }^{13}$

Hvis ikke der er en vis enighed om »det fælles bedste«, går forholdet mellem enkeltmanden og staten i hårdknude. Derfor er det for Grundtvig et hovedspørgsmål, om det er muligt at undgå, at forholdet går i hårdknude? Og hvis 
skaden er sket, om det da lader sig gøre at løse knuden på anden måde end med sværdet?

Det er her, skolen kommer ind som en ny, betydningsfuld institution. Ifølge Grundtvig er skolens historiske opgave nemlig at løse den gordiske knude mellem staten og individet på anden måde end med magt. ${ }^{14}$

»Dette er Knuden, den Gordiske Knude i Menneske-Udviklingen, som hidtil i Grunden altid overhuggedes med Alexander-Sværdet, men maa nødvendig løses med Læmpe og med Taalmodighed, hvor Staten skal reddes og ægte, menneskelig Oplysning skride frem til Dagenes Ende ${ }^{15}$

For at løse knuden mellem den enkelte og staten skulle statsmæssig oplysning træde i stedet for sværdet. Senere talte Grundtvig hellere om folkelig oplysning og folket. Men forskellen er ikke stor. Staten og folket befinder sig inden for samme sfære i den universalhistoriske treklang. Folket er så at sige den kulturelle side af staten. Men hvad enten Grundtvig taler om statsmæssig oplysning eller folkelig oplysning, skal oplysning tjene det overordnede formål at løse knuden - uden at opløse båndene - mellem den enkelte og staten/folket.

\section{Hvad er oplysning?}

I 1784 stillede Kant det berømte spørgsmål: Hvad er oplysning? Det samme gør Grundtvig i Statsmcessig Oplysning. Kant kan betragtes som repræsentant for den forestilling, at oplysning udgår fra universelle principper. I sit skrift stiller Grundtvig imidlertid spørgsmålstegn ved, om der kun findes én form for oplysning. Findes oplysning kun i ental? Eller fmdes der oplysning i flertal? Som oplysninger? Og kan man tale om sand oplysning, hvis der findes mange slags oplysninger?

Grundtvig lægger ikke skjul på, at det er svært at give en klar definition på, hvad oplysning er. »Oplysning er en meget vanskelig Sag at tale om «. Når man begynder at tænke på ordet oplysning, kommer man let til den konklusion, at der gives "saamange Oplysninger - som der er hoveder med Øine i ${ }^{16}{ }^{16}$ Der er med andre ord ligeså mange »oplysninger«, som der er mennesker. Altså hvert individ - sit lys!

Men giver oplysning overhovedet mening, hvis oplysningsbegrebet individualiseres? Ja, på en vis måde siger Grundtvig; »thi netop da jeg var ved at for- 
tvivle over de utallige »oplysninger«, faldt det mig naturligviis ind, at da det træffer sig saa vel, jeg selv ogsaa har et Hoved med Øine i, saa er jeg dermed hjulpet, og veed meget godt hvad jeg selv siger, naar jeg taler om Folks Oplysning, veed nemlig, at det baade først og sidst er deres egen oplysning, jeg mener ${ }^{17}{ }^{17}$ Folks oplysning er først og sidst deres egen oplysning. ${ }^{18}$

For Grundtvig er oplysning ikke et absolut, men et relativt begreb. Verden kan ikke overskues fra et panoptisk punkt, men bliver nødvendigvis set med forskellige øjne. Sandheden træder altid frem i spillet mellem sandheder. Med et moderne begreb kan man sige, at oplysning for Grundtvig er et diskursivt begreb, et kampbegreb. Ingen kan påberåbe sig at sidde inde med den absolutte sandhed. Vi erkender stykkevist og delt.

I Grundtvigs optik begynder oplysning med selv-oplysning, dvs. med individualisering. Han ser en nøje sammenhæng mellem oplysning og individualisering. Oplysningens tro følgesvend er individualisering. Men netop det gør oplysning til et tveægget sværd. Thi hvordan sikre de nødvendige bånd mellem individet $\mathrm{og}$ fællesskabet, når oplysning nødvendigvis fører til stigende individualisering. Oplysning er derfor »et meget tvetydigt Ord», siger Grundtvig. ${ }^{19}$ Oplysning har et janusansigt. Staten kan ligefrem "gaae til Grunde ved Oplysning ${ }^{20}{ }^{20}$

Det skyldes ifølge Grundtvig, at der i virkeligheden både findes en sand oplysning og en falsk oplysning. Den falske oplysning er den, der »bestandig gaaer ud fra Enkelt-Mandens Tarv « ${ }^{21}$ Den form for oplysning er farlig for $» d e t$ Borgerlige Selskab til alle Tider og under alle Himmel-Egne«, fordi ethvert samfund beror på en vis "ÆErefrygt for en højere Ret end Enkelt-Mandens «. ${ }^{22}$ Hvis oplysning undergraver sansen for det fælles og de fælles bånd mellem mennesker, trues det grundlag, som samfundsdannelsen bygger på.

Den sande oplysning tager derimod sit udgangspunkt $i$ det forhold, at vi som individer kun eksisterer i kraft af fællesskabet; ikke kun med folket, men også med hele menneskeheden; »en sådan oplysning, der ved at udstrække sig til hele Menneske-Livet og opvise den dybe Sammenhæng mellem EnkeltManden, Folkets og hele Slægtens Liv, udvikler en for alle de selskabelige Forhold ønskelig Tanke-Gang ${ }^{23}{ }^{23}$

Grundtvigs skoletanker rummer således forestillinger om en form for oplysning, der kan belyse den universalhistoriske treklang mellem enkeltmanden, staten/folket og hele menneskeslægten. 


\section{Folke-lighed}

Grundtvigs højskoletanker bygger på begrebet folk. Et folk, eller en nation, er for Grundtvig en gruppe mennesker, der ejer en indre bevidsthed om, at de hører sammen i kraft af fælles sprog, fælles historie, fælles traditioner og sædvaner. Folket eksisterer ikke i sig selv; det får først eksistens gennem refleksion. Selvrefleksion og eksistens er således to sider af samme sag. Det er refleksionen, der skaber oplevelsen af sameksistens, af et fælles rum, af en kollektiv identitet.

De to helt centrale elementer, der konstituerer et folk, er sproget og historien. Grundtvig er dybt præget af Herders indflydelsesrige synspunkt, at der er identitet mellem sprog og folk. Det er i deres øjne sproget, der definerer et folk og en nation. Sproggrænsen er folkets og nationens grænse. Hver nation taler, som den tænker, og tænker, som den taler. Sproget er indbegrebet af folkets sjæl og folkets ånd. Sproget er det medium, gennem hvilket mennesket bliver sig selv bevidst, og samtidig er det nøglen til forståelse af dets omgivelser.

Sproget knytter også mennesket til fortiden ved at røbe de tidligere slægtleds tanker, følelser og fordomme. Derved bliver fortiden fæstet dybt i menneskets bevidsthed samtidig med, at det ved hjælp af sproget bringer fortiden og nutiden videre ind $\mathrm{i}$ fremtiden. Sproget bliver på den måde udtryk for en levende vækst $\mathrm{i}$ historien. Og menneskene modtager gennem modersmålet og historien en arv. Alle, der i fællesskab deler en historisk og sproglig tradition, er for Herder og Grundtvig et folk eller en nationalitet. Få ideer har fået så stor politisk betydning som denne. Den førte for eksempel til sammenbrud af den multisproglige og multinationale danske helstat. ${ }^{24}$ Grundtvigs synspunkter førte således ikke kun til samfundsmæssig samling, men også til splittelse.

For Grundtvig er folkehøjskolens opgave at styrke kulturen ved at styrke sprogfællesskabet. Ethvert menneske skal gøres bevidst om sin egen kultur. Og midlet er for Grundtvig først og fremmest at søge folkets minder, som de har afsat sig i myter, i poesi, i ordsprog, etc., - og på den måde gøre folkets sprog levende.

Nærmest per definition danner det folkelige en partikulær enhed, et eksklusivt parti, idet folket nødvendigvis må udelukke de andre for at kunne identificere sig selv. Det folkelige udtrykker en etnisk-politisk betydningsdimension. Det folkelige er altid geografisk, etnisk, nationalt, sprogligt, historisk, 
politisk og religiøst bestemt. Man kan sige, at det folkelige altid befinder sig på en skala, der befinder sig mellem en biologisk og en mere universel bestemmelse. Det folkelige kan trække sig sammen om etnos, men har ifølge Grundtvig også indbygget et telos, der rækker ud over identifikationsstrukturen.

I sin disputats Grundtvigs historiefilosofi har Ole Vind klart vist, at Grundtvig funderer sin forståelse af begrebet folk på forældede synspunkter. Han kalder Grundtvigs nationalisme for bibelsk nationalisme, idet Grundtvig altid tog udgangspunkt i den etniske skabelsesmyte i Første Mosebog, kap. 10-11. ${ }^{25}$ Men at Grundtvig baserer sin forståelse af begrebet folk på synspunkter, vi ikke kan tilslutte os i dag, betyder ikke, at hans tanker om folket som et mellemled mellem det individuelle og det universelle er forældede. Det folkelige ophører jo ikke med at spille en konstruktiv rolle i samfundsudviklingen, blot fordi en bestemt måde at fortolke det folkelige på har udlevet sig selv. Evnen til at etablere mellemled mellem enkeltmanden og hele menneskeslægten er stadigvæk grundlag for al samfundsdannelse - i det store, såvel som i det små.

\section{Menneske-lighed}

Grundtvigs skoletanker bygger som sagt på en grundlæggende skelnen mellem folkelivet og menneskelivet. Mens højskolen har det folkelige, nationale og statslige som udgangspunkt, har universitetet det universelle; »et Universitet, der skal svare til sit Navn og sin Bestemmelse, maa have, nære og følge lutter universelle ideer, medens Staten er bundet til det Partielle og Temporcere, saa den lærde og den borgerlige Oplysning kan kun for Følelsen have en dunkel Eenhed i det Folkelige, og fordærve kun hinanden ved at ville klarlig forbinde sig $\ll^{26}$

Der skal være forskel på en folkehøjskole og et universitet, fordi der er forskel på det folkelige og universelle - på samme måde som der er på del og helhed. Men samtidig er der en forbindelse, som dog i det folkelige kun kan være en dunkel følelse. Vil man tvinge folkeligheden til for megen klarhed, går den i stykker eller i hårdknude.

Der skal være forskel på skolen for folkeoplysning og skolen for videnskabelig oplysning, på «Skolen for Livet og Skolen for Lyst, der Begge, hver for sig, kan være gode, men taale ikke at forveksles $« .{ }^{27}$ Universitetet - Skolen 
for Lyst - er også tildels en "Skole for Løier«, idet kun tiden kan vise, hvilke skæve og skøre tanker og billeder om verden, der er holdbare. Om man et århundrede før eller senere rammer det rette, er ikke så afgørende, »thi Skolen for Lyst har Tiden for sig lige til Verdens Ende«. ${ }^{28}$

Grundtvig spørger selv, om man kan forestille sig, at staten støtter et universitet, hvis oplysning rækker ud over statens partikulære interesser. Vil staten ikke anse "Skolen for Lyst« for overflødig, ja, måske ligefrem farlig og skadelig? Det kan man selvfølgelig ikke vide med sikkerhed, men Grundtvig har en tro p̊̊, at staten vil kunne se en fordel i at støtte en institution, der skal beskæftige sig med ॥mennesket i verden«. Der er trods alt en tradition at bygge på, idet staterne i Tyskland og Norden gennem lang tid har støttet noget så umiddelbar unyttigt som det »Philosophiske Facultet«.

Da Grundtvig i 1830'erne og 1840'erne skriver sine skoleskrifter, er det især folkehøjskolen, han beskæftiger sig med, og folkelivet, der udgør forståelseshorisonten. Dog glider universitetet og menneskelivet ikke helt ud af synsfeltet. I skriftet Til Nordmoend om en Norsk Høi-Skole fra 1837, rejser han spørgsmålet: Hvordan spiller folkelig dannelse sammen med "grundig Lærdom og ægte Videnskabelighed«? Højskolen kan ikke klare begge dele. Derfor må der oprettes et nyt universitet.

Grundtvig er da også forvisset om, at når først de nordiske lande hver făr deres folkelige højskole, vil det hurtigt føre til rejsning af »en stor videnskabelig Høiskole ... for Menneske-Livets Udvikling og Forklaring i hele Dets gaadefulde Dybde og herlige Mangfoldighed, altsaa et Universitet ${ }^{29}{ }^{29}$ Løsningen på folkenes gåde ligger ikke på folkelighedens eget nationale beskrivelsesniveau. At løse gåden kræver en institution, hvor man beskæftiger sig med den højeste, universalhistoriske vidskab, dvs. med livet i hele dets logiske og forunderlige sammenhæng.

I Grundtvigs sidste store skoleskrift Det Danske Dummehoved og Den Danske Højskole fra 1847 behandler han forholdet mellem det folkelige og det menneskelige. Han giver her udtryk for en stærk tro på, at det danske folk ikke er »forgabt i sit Eget«, men påskønner »det saakaldt Fremmede ... for ej at gaa Glip ad det Almeen-Menneskelige, hvori naturligviis alt Folkeligt omsider skal finde sit Maal og sin Forklaring ${ }^{30}{ }^{30}$

Vist ingen andre steder i forfatterskabet formulerer Grundtvig sig så klart om sit syn på forholdet mellem det folkelige og det universelle. Lukker det 
folkelige om sig selv, forsvinder den faktor, der kan kaste lys over folkets egne begrænsninger. Det fremmede er en forudsætning for at det folkelige ikke skal tabe den universelle horisont af syne.

Sine universitetstanker udfolder Grundtvig for alvor i skriftet Om Nordens videnskabelige Forening fra 1839, hvor han foreslår et stort fællesnordisk universitet i Göteborg. Her skal der arbejde 300 videnskabsmænd over 30 år til intet mindre end »Ære, Gavn og Glæde for hele Menneskeslægten «. ${ }^{31}$

Universitetet i Göteborg skulle være »eet aandeligt Værksted«, hvor man med forenede kræfter stræber mod det, der er af altomfattende, almen art, mod det universelle. $O g$ det skulle man gøre ved »at bearbeide hele den menneskelige Kundskabs-Kreds til Livets Tarv «. ${ }^{32}$

Grundtvig fastholder, at såvel hvert enkelt individ og hvert enkelt folk indgår i en større universel historie. Universalhistorien skal sikre, at folket fastholder en universal-historisk horisont, så det aldrig glemmes, at menneskelivet ingenlunde klarer sin gåde i det enkelte menneskes eller i det enkelte folks særegne erfaringer, men altid kun »igjennem tusinde Slægter, som et gudddommeligt Experiment, der viser, hvordan Aand og Stöv kan giennemtrænge hinanden $\mathrm{g}$ forklares $\mathrm{i}$ en fælles guddommelig Bevidsthed. Saaledes maa Mennesket opfattes, naar der skal blive en aandelig Videnskabelighed paa Jorden ". $^{33}$

Mange har overset, at dette berømte citat fra indledningen til Nordens Mytologi 1832 handler om universitetet, ikke om højskolen. Universitetets opgave er at sætte individets og folkets egen begrænsede virkelighed ind i en sammenhæng, der går ud over det partikulære. Videnskabelig oplysning skulle opklare den dybe sammenhæng mellem enkeltmanden, folket og hele menneskeslægten. Det var baggrunden for Grundtvigs forslag om et nordisk universitet.

\section{Grundtvigs skoleprogram}

Grundtvigs oplysningsprogram blev imidlertid kun realiseret i stærkt begrænset og beskåret skikkelse. Hvad vi fik, var folkehøjskoler, der bygger på begrebet folk; men hvad der aldrig blev realiseret, var det store fællesnordiske universitet i Göteborg, der skulle have videnskaben som grundlag. At Grundtvig så det 
fællesnordiske universitet som kronen på skoleværket, er der dog ingen tvivl om.

Der er solide historiske grunde til, at det kun var det halve af Grundtvigs skoleprogram, der blev realiseret. Folkehøjskolen blev båret frem af det nittende århundredes folkelige, nationale strømninger, der i Danmark for alvor brød igennem efter det katastrofale nederlag i 1864. Det var dette nederlag, der gjorde landet til den nationalstat, vi i Danmark siden har været så stolte af, og som ligeledes gjorde den grundtvigske folkehøjskole til den enestående skoleform, vi også har været stolte af.

Her ved indgangen til det enogtyvende århundrede ser verden imidlertid meget anderledes ud. Ikke mindst de sidste årtiers europæiske og globale bevægelse har sat den traditionelle grundtvigske selvforståelse under et stærkt pres. Fælles problemer som dem, der følger af den voksende individualisering og globalisering, bliver stadig vanskeligere at imødegå inden for rammerne af det traditionelle grundtvigske livssyn.

Men samtidig er det tydeligt, at vi som mennesker stadig behøver »mellemled« mellem »det individuelle« og »det globale«. Som mennesker må vi kunne identificere os med et $॥ v i \ll$, der udgør en form for bindeled mellem den enkelte og det hele. At kunne indgå i lokale livssammenhænge, hvis eksistens kan symboliseres, og hvis historie kan fortælles, synes således at være et grundlæggende behov.

For Grundtvig var det derfor et afgørende spørgsmål, hvordan et sådant ॥vi« undgår den fare at lukke sig om sig selv. Om end han ikke altid selv undgik faren, ${ }^{34}$ er hans tankeunivers domineret af den forestilling, at det folkelige i sidste instans skal finde sin forklaring i det almenmenneskelige. Når han ikke skrev en rigtig danmarkshistorie, men flere verdenshistorier, skyldes det i høj grad, at han ønskede at fastholde den nationale fortælling i et universalhistorisk perspektiv.

Behovet for et globalt perspektiv på verdenssamfundets udvikling er så stort som nogensinde. Derfor er der grund til at interessere sig for helhedssynet $\mathrm{i}$ Grundtvigs oplysningsprogram, dvs. for den universalhistoriske treklang mellem det individuelle, det folkelige og universelle. Med Grundtvigs egne ord er det nemlig ønskeligt at fremme en oplysning, der kan »opvise den dybe Sammenhæng mellem Enkelt-Manden, Folkets og hele Slægtens Liv « ${ }^{35}$ 
Som sagt har den pædagogiske og den skolehistoriske tilgang til Grundtvigs oplysningsprogram bevirket, at den universelle dimension ikke for alvor er blevet belyst. Men tiden synes nu moden til at beskæftige sig med Grundtvigs oplysningstanker i deres helhed.

\section{Noter}

1. K.E. Bugge »Grundtvigs pædagogiske tanker'. I: Grundtvig og Grundtvigianisme i nyt lys, $210 \mathrm{ff}$.

2. Anf. skr.

3. Roar Skovmand »Den grundtvigske højskole«. I: Grundtvig og Grundtvigianismen i nyt lys, 1983:334.

4. Værker i Udvalg, bind 4, s.XIX.

5. Danne-Virke bd. 4 1819: 140f.

6. Danne-Virke bd. 1 1816: 117.

7. Danne-Virke bd. 2 1817: 118-206. Optrykt i: Ove Korsgaard (red.) En Orm - en Gud, 1997.

8. Grundtvig Statsmoessig Oplysning 1983:45.

9. Grundtvig Statsmoessig Oplysning 1983:79.

10. Det gør han i verdenshistoriens tredje del fra 1843

11. Jf. Sigurd Aa. Aarnes »Grundtvig som historiker « I: Grundtvig og grundtvigianisme i nyt lys, 1983:66.

12. Grundtvig Statsmoessig Oplysning 1983:59.

13. Grundtvig bruger ofte knuden som metafor om såvel personligheden som interpersonelle forhold. Når det gælder personligheden, anbefaler han at overhugge knuden, når det gælder interpersonelle forhold, anbefaler han at fare med lempe. Jf. »Om Kirke, Stat og Skole I: Danne-Virke bd. 4 1819: 319 «, samt »Om Mennesket i Verden «. I: En Orm - en Gud, 1997:186.

14. Grundtvig Statsmoessig Oplysning 1983:31.

15. Grundtvig Statsmaessig Oplysning 1983:67f.

16. Grundtvig Statsmoessig Oplysning 1983:68.

17. Grundtvigs tiltro til » egen oplysning « bygger på den opfattelse, at alle i ordet har adgang til oplysning om livet. Alle mennesker har i det $»$ lille $\ll$ ord del i det $»$ store $\ll$ ords logos. Det centrale skriftsted for Grundtvigs ord-teologi er Johannesprologen, hvis indledning ligger til grund for hele Grundtvigs oplysnings- og $»$ forklarings $\ll$-program.

18. Grundtvig Statsmoessig Oplysning 1983:26.

Grundtvig Statsmoessig Oplysning 1983:31.

19. Grundtvig Statsmoessig Oplysning 1983:28.

20. Grundtvig Statsmcessig Oplysning 1983:27

21. Grundtvig Statsmaessig Oplysning 1983:31 
22. Jeg har i Kampen om lyset. Dansk voksenoplysning gennem 500 år, og i Kundskabskapløbet. Uddannelse $i$ videnssamfundet,nærmere behandlet den danske helstats sammenbrud.

23. Første gang Grundtvig lagde den etniske skabelsesmyte til grund for sine betragtninger er i Verdens Krønike fra 1814.

24. Grundtvig Statsmoessig Oplysning 1983:65.

25. Grundtvig Statsmoessig Oplysning 1983:65.

26. Statsmæssig Oplysning 1983:66.

27. Grundtvigs skoleverden bd. II, 1968:77.

28. Grundtvigs skoleverden bd. II, 1968:234.

29. Grundtvig: »Nordens Videnskabelige Forening « I: Grundtvigs Skoleverden II 1967:148.

30. Do. s. 149.

31. Fra »Nordens Mytologi«. I: Udvalgte Skrifter 5:408.

32. Grundtvigs udelukkelse af digteren Goldschmidt fra det danske »vi« er et eksempel herpå. Se »Svar paa Hr. Goldschmidts Udfordring til Danskheden « i: Danskeren nr. 44, 1850.

33. Grundtvig Statsmoessig Oplysning 1983:31.

\section{Litteratur}

Allchin, A. M. N. F. S. Grundtvig. An Introduction to his Life and Work, Aarhus University Press, 1997.

Bugge, K. E. (red.) Grundtvigs skoleverden i tekster og udkast, I-II, København 1968.

Bugge, K. E. »The School for Life. The Basic Ideas of Grundtvig's Educational Thinking «. In: Heritage and Prophecy, (red.) Allchin, A. M. et al., Aarhus 1993

Grundtvig, N. F. S. Danne-Virke, København 1816-19.

Grundtvig, N. F. S. Statsmoessig oplysning, udgivet af Bugge, K. E. and Nielsen V., København 1983

Henningsen, Hans. "The Danish Folk High School«. In: Heritage and Prophecy 1993.

Jonas, Uffe. »Det individuelle, det folkelige, det universelle« 1999. (Upubliceret manus).

Korsgaard, Ove. (red.) En Orm - en Gud. Om mennesket $i$ verden, Odense 1997.

Korsgaard, Ove. Kampen for lyset. Dansk voksenoplysning gennem 500 år. København 1998. 
Korsgaard, Ove. Kundskabskapløbet. Uddannelse i videnssamfundet. København 1999.

Kaae, Lars »Ikkun som voxne Menneske-Børn: Grundtvig og frihed«. I: Stykkevis og delt. Århus 1986.

Løgstrup, K. E. »Højskolens nye fronter«. In: Højskolen til debat, (red.) Rosendahl, Johannes, København 1961

Skovmand, Roar. »Den grundtvigske folkehøjskole«. I: Grundtvig og grundtvigianismen $i$ nyt lys, (red.) Thodberg, Christian and Thyssen, Anders Pontoppidan, Aarhus 1983

Vind, Ole. Grundtvigs historiefilosofi, København 1999.

Aarnes, Sigurd Aa. »Grundtvig som historiker «. I: Grundtvig og grundtvigianisme i nyt lys. Aarhus 1983. 